\title{
WHAT EMPLOYERS MAY LEARN FROM ENGLISH HIGHER EDUCATION INSTITUTIONS: A FORTIGENIC APPROACH TO OCCUPATIONAL STRESS
}

\author{
M.Y. TYTHERLEIGH \\ University Of Plymouth \\ United Kingdom
}

\begin{abstract}
Whilst there is no denying that levels of occupational stress in staff working in universities and colleges are increasing, academic staff, in particular, continue to maintain a level of satisfaction from their jobs. A stratified random sample of staff working in 14 higher education institutions in England was used. The results showed that, whilst commitment was lower and levels of occupational stress were significantly higher with regard to work relationships, control and resources and communication, compared to the normative data, staff reported significantly lower levels of stress relating to work-life balance, overload, and job dissatisfaction. Compared to normative data, participants reported significantly lower levels of physical ill-health and psychological outcomes of stress. The results support previous findings identifying a protective effect of job satisfaction against the negative consequences of workplace stress.
\end{abstract}

\section{OPSOMMING}

Terwyl dit nie ontken word dat die vlak van werkstres van personeel wat in universiteite en kolleges werk, verhoog nie, ervaar akademiese personeel steeds tevredenheid met hul werk. 'n Gestratifiseerde ewekansige steekproef van personeel wat by 14 hoër opvoedkundige instellings in Engeland werk, is geneem. Die resultate het aangetoon dat hoewel verbondenheid laer en werkstres beduidend hoër was ten opsigte van werksverhoudinge, kontrole en bronne en kommunikasie vergeleke met normatiewe data, personeel beduidend laer vlakke van stres ten opsigte van werklewe balans, oorlading en werkstevredenheid getoon het. Deelnemers het ook beduidend laer vlakke van fisieke ongesondheid en psigologiese uitkomstes van stres gerapporteer. Die resultate ondersteun vorige bevindings wat ' $n$ beskermende effek van werkstevredenheid teen die negatiewe uitkomstes van stres identifiseer.

According to a recent article by Rothmann (2003, p. 3), the health and social sciences have traditionally been characterised by a pathogenic paradigm, i.e., an orientation towards the abnormal. Thus, the emphasis has been on what makes people ill as opposed to what makes them well (Strümpfer, 2000). However, with the introduction of 'positive psychology' and its focus on human strengths and optimal functioning rather than on the weaknesses and malfunctioning (Ryan \& Deci, 2000; Seligman \& Csikszentmihayli, 2000), more recent attempts to discover 'what can go right' as opposed to 'what can go wrong' are starting to take place. For example, in organisational psychology, the aim is to find the 'happy/productive' worker (Staw, 1986), and focus more on positive concepts such as job satisfaction, organisational commitment, organisational citizenship behaviour and intrinsic motivation (Schaufeli \& Bakker, 2001). Whilst some studies have failed to establish a positive relationship between job satisfaction and job performance (Iaffaldano \& Muchinsky, 1985), others suggest that job satisfaction can protect against the physical and psychological effects of long-term stress (Mechteld, Visser, Smets \& Oort, 2003; Ramirez, Graham, Richards, Cull \& Gregory, 1996). For example, in their study of stress, satisfaction and burnout among Dutch medical specialists, Mechteld et al. (2003) identified a protective effect of job satisfaction against the negative consequences of work stress. That is, despite reporting relatively high levels of stress, they also reported high levels of job satisfaction.

Occupational stress is an area of organisation psychology that has received attention recently, and is seen by many British employers as one of the most important workplace health and safety issues (Health and Safety Executive, 2000). It is associated with increases in stress outcomes, such as job dissatisfaction, illhealth, absenteeism, higher turnover and lower productivity (Jones \& Bright, 2001). There is also a wealth of evidence to show that workers involved in high levels of personal interaction (e.g., nurses, doctors, teachers, lecturers) are particularly vulnerable to occupational stress. For example, psychological stress now appears to be a feature of occupational life for university staff

Requests for copies should be addressed to: M Thytherleigh, Faculty of Health and Social Care, University of Plymouth, Devon EX2 6AS, United Kingdom
(Fisher, 1994), occurring not only in increasing levels in academics in the United Kingdom (UK) (e.g., Kinman \& Jones, 2003), but also in Australia and New Zealand (e.g., Boyd \& Wylie, 1994; Gillespie, Walsh, Winefield, Dua \& Stough, 2001; Winefield et al., 2003). For example, in their longitudinal study of occupational stress in 17 Australian universities, Winefield et al. (2003) found that $43 \%$ of academic staff $(N=3711)$ compared to $37 \%$ of general staff $(N=4655)$ were classified as possible 'cases' of psychological illness using the General Health Questionnaire (GHQ-12, Goldberg \& Williams, 1988). This compared to a $12 \%$ case rate in the Australian population overall. In her study of university staff in the UK, Kinman (2001) reported a 53\% 'case' rate amongst academic staff.

One of the reasons why occupational stress in university staff is of particular interest is that, from an historical perspective and in contrast to other types of organisations, working in academia has generally been considered relatively stress-free and highly satisfying (Willie \& Stecklein, 1982). Indeed, factors in other occupational groups often associated with high levels of stress and/or job dissatisfaction have, until recently, not tended to produce the same effects for academics. For example, Watts et al. (1991) found that $75 \%$ of university workers who reported long working hours, work overload and lack of support were still satisfied with their jobs. Doyle and Hind (1998) also found that $40 \%$ of university lecturers in their sample who reported long working hours and high levels of burnout still found their jobs intrinsically motivating, enjoyable and potentially rewarding. Thus, in comparison to other professions, academic work is 'somewhat unusual' (Kinman, 2001).

One explanation for these differences arises from differences in work context factors. For example, in contrast to other occupational groups, working in academia is generally associated with higher levels of autonomy, clarity and tenure, and a 'collegiate culture' which emphasises consensual decisionmaking and shared values (French, Caplan \& Van Harrison, 1982). There also appear to be differences in the ways academics experience their working conditions: they are intrinsically motivated by their disciplines and related teaching and research 
tasks (Lacy \& Sheehan, 1997; McInnis, 1996, 1999), especially when they have clear and achievable roles, challenging tasks, supportive supervisors and an organisational structure which permits them to influence decision-making (Winter \& Sarros, 2002). Individuals who perceive that they can control their environment are less likely to suffer stress (Makin, Cooper \& Cox, 1996).

In 1996, however, the results of an international survey of the academic profession carried out using data from 14 countries (i.e., Australia, Brazil, Chile, England, Germany, Hong King, Israel, Japan, Korea, Mexico, The Netherlands, Russia, Sweden and United States) reported that significant changes had taken place in higher education (Altbach, 1996). For example, academics are now faced with demands for greater accountability, value for money, efficiency and quality, and an increase in remote and autocratic management styles (e.g. AUT, 1990). There has also been gradual erosion in pay and job security and, with the abolition of tenure in the 1980s, increasing numbers of staff appointed on fixed-term contracts. Moreover, these changes in conditions are now being reflected in levels of job satisfaction and commitment. For example, a recent study of levels of job satisfaction experienced by academics from Australia, Germany, Hong King, Israel, Mexico, Sweden and the UK showed that fewer than $50 \%$ of British academics were generally satisfied with their jobs (Lacy \& Sheehan, 1997). Kinman and Jones (2003) found that $71 \%$ of their sample of academics found their jobs rewarding and worthwhile and $74 \%$ maintained they were still intellectually stimulated by their work. Nonetheless, $52 \%$ of respondents reported that they felt less job satisfaction than in recent years. Indeed, a national survey of attitudes to work carried out in the UK (Millward-Brown, 1996) found that university and college lecturers and researchers reported lower levels of job satisfaction and job security than 20 other occupational groups. Moreover, a more recent epidemiological study of job satisfaction in 143 occupational groups in the UK placed 'university and polytechnic teaching professionals' in the bottom $25 \%$ (Rose, 1999).

A recent nationwide study of all categories of employees working in 14 higher education institutions (HEIs) in England, however, suggests that, despite this gradual erosion of job factors that once appeared to 'buffer' academics, higher levels of job satisfaction remain. This study used the ASSET questionnaire (Cartwright \& Cooper, 2002), which recognises that job dissatisfaction can be the outcome of work-related stress as well as a source of stress. It found that, whilst commitment levels were lower and levels of occupational stress were significantly higher in relation to work-relationships, control and resources, as well as communication compared to other occupational groups, HEI staff (non-academic as well as academic staff) reported statistically significantly lower levels of stress in relation to work-life balance, overload and job overall. They also reported statistically significantly lower levels of physical illhealth outcomes of stress and normative levels of psychological outcomes. Similar high levels of satisfaction in certain aspects of their work, together with high levels of perceived stressors and strains, were also identified by Doyle and Hind (1998) in their study of psychology lecturers. More recently, Kinman and Jones (2003) also found that several respondents thrived on the fact that their jobs were stressful, although they acknowledged 'that it is going too far at the moment' (p. 26).

\section{The present paper}

The purpose of this paper, therefore, is to report the results from this nationwide study of occupational stress levels in 14 English HEIs where, compared to the normative data, staff reported lower levels of stress. In particular, it reports the results for work-life balance, overload, job overall and physical outcomes of stress. Moreover, having good convergent validity with the Warr Job Satisfaction Scale (Warr, Cook \& Wall, 1979), the scores for the job overall subscale of the ASSET will be treated as an outcome measure of job satisfaction. The convergent validity of the job overall scale with the Warr Job Satisfaction Scale was investigated in a sample of support staff from a call centre for a northern police department $(N=488)$. The correlation coefficient showed a strong negative relationship (i.e., high levels of stress for job overall related to low levels of job satisfaction) of $r=-0,606, p<$ $0,01)$. This negative relationship was expected because the ASSET scale is reversed, compared to the Warr scale. Winefield et al. (2002) used the Warr Job Satisfaction Scale to measure the levels of job satisfaction between academic and non-academic university staff working in Australian universities. They found that the lowest levels of job satisfaction were reported by academics involved in teaching only or in both teaching and research. In contrast, a study of occupational stress in one UK university carried out by Bradley and Eachus (1995) following a period of considerable organisational change found no differences in job satisfaction between the different occupational groups. Bradley and Eachus used the Occupational Stress Indicator (Cooper, Sloan \& Williams, 1988) to measure levels of job satisfaction and, compared to the norm, they found that overall university staff were less satisfied with their jobs. They also found that, compared to the norm, HEI staff reported more frequent symptoms of physical ill-health.

\section{METHOD}

\section{Sample}

Data were obtained from a stratified random sample of 3808 employees working in 14 universities and higher education colleges throughout England. These comprised eight 'old' universities established pre-1992, five 'new' universities (i.e., former polytechnics) established post-1992 and one nonuniversity status HEI.

Instrument - the ASSET (Cartwright \& Cooper, 2002)

Full details of the ASSET are described elsewhere (Cartwright \& Cooper, 2002; Johnson \& Cooper, 2003). In summary, this tool comprises four main questionnaires. The first three cover sources and outcomes of stress (i.e., Perceptions of your Job, 37 items relating to eight sources of stress; Attitudes towards your Organisation, 9 items measuring commitment levels; and Your Health, 19 items measuring the frequency of physical and psychological ill-health symptoms of stress). The fourth questionnaire - Supplementary Information - consists of 24 customised items which are specific to HEIs. The ASSET has an established set of norms from a database of responses from 9188 workers in public and private sector (non-HEI) organisations in the UK.

\section{Procedure}

A total of 10,090 anonymous questionnaires (representing 23\% of the population) were sent to a stratified random sample of full- and part-time staff in a convenience sample of 14 English HEIs. Fifty-four percent were sent to employees working in old universities, $40 \%$ to those in new universities, and the remaining $6 \%$ to employees in a non-university status HEI. Questionnaires were sent out with an information sheet and stamped addressed envelope, with full instructions to return any completed questionnaires direct to the researchers within four weeks of receipt.

\section{Statistical analysis}

As the study used a stratified random sample, all mean scores for HEIs and category of employee have been weighted by population size. Because raw data were not available for the normative samples, a series of Student-t tests were used to compare the study mean scores with those from the normative sample (unweighted). The significance level was adjusted using a Bonferroni correction to take into account the number of comparisons made. Correlations, Principal Component Analysis and stepwise Linear Regression procedures were performed where necessary using SPSS 11.0.1 (SPSS Inc., 2003). 


\section{RESULTS}

\section{Reliability of the ASSET}

A series of Cronbach's alphas was carried out on each of the questions for the five ASSET subscales to identify the reliability of the ASSET questionnaire with these data. The results ranged from $0,64-0,94$, showing good reliability.

\section{Response rate}

The overall response rate was 38\%, with 3808 usable questionnaires being returned. Thirty-five per cent of respondents were academic and research (A\&R) staff $(N=1329)$, $30 \%$ administrative and clerical (A\&C) staff $(N=1114), 25 \%$ Academic-support staff (i.e., technical, computing and library staff; $N=940$ ) and $10 \%$ Facility-support staff (e.g., caterers, cleaners, estates/craftworkers and security staff; $N=38$ ).

\section{Participants}

Forty-one per cent of participants were male $(N=1437)$ and $57 \%$ were female $(N=2052)$; the remaining $2 \%(N=73)$ did not provide gender details. Seventy-four per cent were aged at least 36 years and $88 \%$ were of White British ethnicity.

\section{Job characteristics}

Seventy-eight per cent of respondents worked full-time and 78\% were employed on permanent contracts. By category of employee, $71 \%$ of A\&C staff, $72 \%$ of Academic-support staff and $63 \%$ of Facility-support staff worked 31-40 hours in a typical week. In contrast, the highest numbers of $A \& R$ staff (38\%) worked 41-50 hours in a typical week, with a further $40 \%$ doing 51-61 or more hours.

For the purposes of confidentiality and anonymity, details of job grade were not obtained during this study. However, other job characteristic details, including salary levels and details of management responsibilities, were obtained. Forty-two per cent of respondents earned between $£ 10,001-£ 20,999$ per year, $25 \%$ earned between $£ 21,000-£ 30,999$, and $25 \%$ earned at least $£ 31,000$ per year. (The average UK national income is between $£ 24,000-£ 27,000$ per year; (Office for National Statistics, 2003). On the basis that senior management staff receive salaries at a minimum of $£ 31,000$, this suggests that $75 \%$ of respondents were employed in lower level positions. Sixty-five per cent of respondents had no management responsibilities, although $1 \%$ were responsible for managing a budget only, 20\% were responsible for supervising/managing others, and $14 \%$ had both sets of responsibilities.

\section{Differences in stress levels}

Table 1 shows the means and standard deviations (weighted by population size) by category of employee compared to the norm. Overall, HEI staff (irrespective of category of employee) were statistically significantly less stressed by: work-life balance $(p<0,01)$ : overload $(p<0,01)$; and job overall $(p<0,01)$, i.e., they were more satisfied with their jobs. They also reported statistically significantly lower levels of physical ill-health outcomes of stress $(p<0,01)$ and normative levels of psychological ill-health (not significant) (NS).

A comparison of the weighted means by category of employee showed statistically significant differences between the four groups for work-life balance, overload, job overall and physical ill-health (all at $p=0,0001$ ), but not for psychological wellbeing. Moreover, even when those personal and job characteristics which previous research has shown can influence stress levels (e.g., gender, type of university, salary level, hours worked in a typical week, full-time vs. part-time employment, type of contract and management responsibilities) were controlled for, significant differences (at $p<0,05$ ) still remained. A series of post-hoc analyses showed that, by category of employee, $A \& R$ staff reported the highest levels of stress relating to work-life balance and overload $(p<0,05)$. In contrast, however, Facilitysupport staff reported the lowest levels of job satisfaction and, together with A\&C and Academic-support staff, the highest levels of physical ill-health $(p<0,05)$.

TABLE 1

COMPARISON OF MEAN SCORES BYCOMPARISON OF MEAN SCORES BY CATEGORY OF CATEGORY OF EMPLOYEE EMPLOYEE WITH THE NORM

\begin{tabular}{|c|c|c|c|c|c|c|c|c|c|c|}
\hline \multirow[b]{3}{*}{ Variable } & \multicolumn{10}{|c|}{$\begin{array}{l}\text { Category of employee } \\
\text { (weighted values) }\end{array}$} \\
\hline & \multicolumn{2}{|c|}{$\begin{array}{l}\text { Normative values } \\
\text { (unweighted) }\end{array}$} & \multicolumn{2}{|c|}{ s $A \& R$} & \multicolumn{2}{|c|}{$\mathrm{A} \& \mathrm{C}$} & \multicolumn{2}{|c|}{$\begin{array}{l}\text { Academic- } \\
\text { support }\end{array}$} & \multicolumn{2}{|c|}{$\begin{array}{l}\text { Facility- } \\
\text { support }\end{array}$} \\
\hline & Mean & SD & Mean & SD & Mean & SD & Mean & SD & Mean & SD \\
\hline $\begin{array}{l}\text { Work-life } \\
\text { balance }\end{array}$ & 12,49 & 4,77 & 14,31 & 4,67 & 9,18 & 3,71 & 10,47 & 4,02 & 10,58 & 4,94 \\
\hline Overload & 12,88 & 4,55 & 13,39 & 4,63 & 10,97 & 4,46 & 11,52 & 4,39 & 9,57 & 4,11 \\
\hline $\begin{array}{l}\text { Job } \\
\text { overall }\end{array}$ & 25,64 & 6,31 & 22,01 & 5,77 & 22,49 & 5,96 & 24,25 & 5,94 & 26,15 & 7,48 \\
\hline $\begin{array}{l}\text { Physical } \\
\text { health }\end{array}$ & 14,16 & 4,07 & 13,05 & 4,10 & 14,16 & 3,94 & 13,47 & 3,99 & 13,96 & 4,08 \\
\hline $\begin{array}{l}\text { Psychological } \\
\text { health }\end{array}$ & 23,95 & 7,52 & 23,91 & 7,38 & 23,65 & 7,21 & 23,53 & 7,15 & 22,98 & 7,74 \\
\hline
\end{tabular}

A comparison of the results by category of employee showed that, whilst A\&C and Academic-support staff were statistically significantly less stressed by work-life balance, overload and job overall (all at $p<0,01$ ), A\&R staff were more stressed than the norm by work-life imbalance $(p<0,01)$ and overload $(p<$ $0,01)$. In particular, compared to the norm, A\&R staff were more stressed by having to work longer hours than they wanted to, having to work unsocial hours, spending too much time travelling in their jobs and having work interfere with their home and personal life. They also felt they were given unrealistic deadlines and unmanageable workloads. Notwithstanding this, A\&R staff were still less stressed by their jobs overall compared to the norm (i.e., they were more satisfied with their jobs). They also reported statistically significantly lower levels of physical ill-health $(p<0,01)$ outcomes of stress and normative levels of psychological illhealth (NS). Facility-support staff, however, were less stressed than the norm by work-life balance and overload, but reported normative levels on job overall (NS). They also reported normative levels of physical ill-health as well as psychological ill-health outcomes of stress (NS).

\section{Relationships between sources and outcomes of stress}

Relationships between sources and outcomes of stress were all statistically significant and positive at $p=0,0001$, both irrespective of and by category of employee. This shows that high levels of stress relating to work-life balance and overload were related to high levels of job dissatisfaction (i.e., high job overall scores), physical ill-health and poor psychological wellbeing. High levels of job dissatisfaction were also related to poor health outcomes of stress.

\section{Predictors of outcomes of stress}

A series of stepwise multiple regression analyses were carried out to identify the predictors of job satisfaction, physical health and psychological wellbeing. For these analyses, all ASSET sources of stress (i.e., work relationships, work-life balance, overload, job security, control, resources and communication, pay and benefits, commitment perceived from the organisation and commitment to the organisation) but excluding job overall when this was treated as an outcome measure for job satisfaction, were entered separately. In addition, gender, category of employee, type of university, salary level, hours worked in a typical week, employed hours (i.e., full-time vs. part-time), type of contract and management responsibilities, were also entered into the 
model. Table 2 presents the seven predictors that account for almost $50 \%$ of the variance in job satisfaction. As shown, control was the strongest predictor, accounting for $39 \%$ of the variance.

TABLE 2

MULTIPLE REGRESSION ANALYSES OF ASSEST SOURCES OF STRESS (EXCLUDING JOB OVERALL), GENDER AND JOB CHARACTERISTICS, WITH JOB OVERALL AS THE DEPENDENT VARIABLE

\begin{tabular}{lccccc}
\hline Variable & Multiple R & R square & F & Beta & $\begin{array}{c}\text { \% of } \\
\text { variance }\end{array}$ \\
\hline Control & 0,625 & 0,391 & 16860,94 & 0,291 & 39 \\
Work relationships & 0,660 & 0,435 & 1011,14 & 0,203 & 5 \\
Overload & 0,672 & 0,452 & 720,65 & 0,134 & 1 \\
Category of employee & 0,688 & 0,474 & 589,77 & 0,138 & 2 \\
Work-life balance & 0,696 & 0,484 & 491,93 & 0,148 & 1 \\
Commitment from & 0,703 & 0,494 & 426,78 & $-0,126$ & 1 \\
organisation & & & & & \\
Type of contract & 0,706 & 0,499 & 372,91 & $-0,081$ & 0,5 \\
\hline
\end{tabular}

Table 3 presents the six predictors that account for $23 \%$ of the variance in physical health. In contrast to job satisfaction, control does not feature in this model. However, work relationships, work-life balance and overload, which together accounted for $7 \%$ of the variance in job satisfaction scores, also account together for $6 \%$ of the variance in physical ill-health. When job overall is not included in the model, workrelationships become the strongest predictor of physical health, accounting for just over $11 \%$ of the variance in scores, illustrating the significant contribution of job satisfaction in the prediction of physical health.

TABLE 3

MULTIPLE REGRESSION ANALYSES OF ASSET SOURCES OF STRESS

(INCLUDING JOB OVERALL), GENDER AND JOB CHARACTERISTICS, WITH PHYSICAL HEALTH AS THE DEPENDENT VARIABLE

\begin{tabular}{lccccc}
\hline Variable & Multiple R & R square & F & Beta & $\begin{array}{c}\% \text { of } \\
\text { variance }\end{array}$ \\
\hline Job overall & 0,362 & 0,131 & 385,34 & 0,177 & 13 \\
Gender & 0,403 & 0,162 & 247,52 & 0,160 & 3 \\
Overload & 0,441 & 0,195 & 206,17 & 0,162 & 3 \\
Salary & 0,457 & 0,209 & 169,22 & $-0,172$ & 2 \\
Work relationships & 0,470 & 0,221 & 145,07 & 0,138 & 2 \\
Work-life balance & 0,479 & 0,230 & 127,18 & 0,125 & 1
\end{tabular}

Table 4 presents the six predictors that account for almost $33 \%$ of the variance in psychological wellbeing. The predictors here are almost identical to those for physical health, except that commitment perceived from the organisation is a predictor for psychological health and not physical health, whereas salary is a predictor for physical health and not psychological health. The strongest predictor for psychological wellbeing is work relationships. This accounts for $21 \%$ of the variance, even when job overall is not included in the analysis.

In summary, these results show that personal characteristics and job characteristics explained only $1-5 \%$ of the variance in satisfaction and stress. Perceived levels of stress relating to the job, however, explained less than half of the variance in job satisfaction, only $22 \%$ of physical ill-health outcomes of stress and only $32 \%$ of psychological ill-health outcomes of stress.
TABLE 4

MULTIPLE REGRESSION ANALYSES OF ASSET SOURCES OF STRESS (INCLUDING JOB OVERALL), GENDER AND JOB CHARACTERISTICS, WITH PSYCHOLOGICAL WELL-BEING AS THE DEPENDENT VARIABLE

\begin{tabular}{lccccc}
\hline Variable & Multiple R & R square & F & Beta & $\begin{array}{c}\% \text { of } \\
\text { variance }\end{array}$ \\
\hline Work relationships & 0,459 & 0,211 & 676,23 & 0,182 & 21 \\
Overload & 0,526 & 0,277 & 485,65 & 0,238 & 6,5 \\
Job Overall & 0,547 & 0,299 & 359,70 & 0,149 & 2 \\
Gender & 0,561 & 0,314 & 290,41 & 0,138 & 1 \\
$\begin{array}{l}\text { Commitment perceived } \\
\text { from organisation }\end{array}$ & 0,569 & 0,324 & 242,92 & $-0,118$ & 1 \\
\begin{tabular}{l} 
Work-life balance \\
\hline
\end{tabular} & 0,573 & 0,328 & 205,72 & 0,075 & 1 \\
\hline
\end{tabular}

\section{DISCUSSION}

The key findings of this study, therefore, were the higher levels of job satisfaction and lower levels of physical ill-health outcomes of stress compared to the norm in a stratified random sample of all categories of HEI staff working in 14 universities and HE colleges in England. Despite reporting higher levels of stress relating to job insecurity, work relationships, control and resources and communication, and lower levels of commitment to and from their organisations compared to the norm, HEI staff were more satisfied with and reported less frequent symptoms of physical ill-health from the work they do. Thus, the results of our study do not support the higher levels of job dissatisfaction and more frequent symptoms of physical illhealth compared to the norm reported by academic and nonacademic staff working in the British university studied by Bradley and Eachus (1995). Moreover, apart from Facilitysupport staff, who reported similar levels to the norm, these more positive outcomes of stress were reported by academic, as well as non-academic, staff. Thus, our results also do not support the higher levels of job dissatisfaction reported by academic compared to non-academic staff working in Australian universities identified by Winefield et al. (2002).

Interestingly, the study by Bradley and Eachus was carried out in a new university. Although not reported in this paper, a previous analysis of our results by university type (see Tytherleigh et al., in press) showed that, compared to old universities, staff working in new universities reported statistically significantly lower levels of job satisfaction as well as more frequent symptoms of physical ill-health outcomes of stress. Thus, Bradley and Eachus' results fit with ours.

Whilst it is obviously impossible to generalise our findings to all HEIs, our results suggest that in our sample, English HEIs are still providing the types of working conditions (particularly for $A \& R$ staff) that motivate their staff to meet the sources of stress headon. This does not, however, imply that these HEI staff will never run the risk of experiencing job dissatisfaction and more frequent physical ill-health. Indeed, as shown by Winefield et al. (2002), when stress was high and job satisfaction low, levels of psychological strain - a potential precursor to physical ill-health increased considerably. Moreover, since there is clear evidence that stress levels in HEI staff are increasing (e.g., Kinman \& Jones, 2003), explanations for these differences in job satisfaction results identified by our study compared to those found in Australian universities may be a learning point for English universities.

Our findings also suggest that, compared to the norm, higher levels of job satisfaction might have protected staff 
against some of the physical outcomes of stress. This protective effect was previously identified by Mechteld et al. (2003) and Ramirez et al. (1996) in their studies of stress, satisfaction and burnout in medical specialists. Apart from a humanitarian perspective, i.e., work-related satisfaction has been shown to be a major component of satisfaction with life (Howard \& Frink, 1996), a healthy and happy worker can also be a productive worker (Staw, 1986). For example, increased absenteeism, lost productivity and low levels of commitment can often be a pressing concern for organisations. Cranny, Smith and Stone (1992) noted that job satisfaction has been shown to influence attendance at work, pro-organisational behaviours and decisions to leave the organisation or to retire. Also, compared to dissatisfied workers, satisfied workers are often more committed to their organisations.

Whilst the results of our study showed statistically significant positive relationships between all three outcomes of stress (all at $p<0,0001$ ), in contrast to Mechteld et al. (2003) and Ramirez et al. (1996), they do not suggest any direct protective effects of job satisfaction against the psychological effects of long-term stress. However, whilst the frequency of psychological symptoms of stress in our study were at normative levels, they were also not at the high levels of 'caseness' previously identified in university staff by Winefield et al. (2002) and Kinman (2001). Moreover, if stress levels of university staff were to increase (as the evidence predicts) and job satisfaction levels decrease (as in Australian universities), it seems reasonable to assume that the frequency of psychological and any associated physical ill-health symptoms might also increase in English HEIs. In conclusion, the higher than the norm levels of job satisfaction identified by our study may explain why the frequency of psychological stress symptoms are currently at normative, and not higher than the norm, levels.

An important criticism of this comparison, however, is the use of different instruments to measure psychological strain. The GHQ-12 is a well-known psychiatric screening instrument, recommended as a valid indicator of mental health (psychological strain) in occupational stress research (Banks et al., 1980). It relates to the respondent's experiences of health over the last few weeks and how this compares to 'usual'. In contrast, the present study used the Psychological Wellbeing subscale of the ASSET. This was designed to give an insight into the mental health of the respondent rather than a detailed clinical diagnosis (Johnson \& Cooper, 2003), and focuses on the frequency and experience of health items (e.g., mood swings, constant irritability) over the last three months. Consequently, whilst there is evidence of good convergent reliability between the two scales (Johnson \& Cooper, 2003), the use of different measures, especially those where the emphasis is different, makes direct comparisons impossible.

Compared to previous research, the lower than the norm levels of psychological ill-health for HEI staff were somewhat surprising, as were the lower than the norm levels of stress relating to work-life balance and overload. For example, there is an abundance of previous research reporting the long working hours and impact of work on home-life balance in academics (e.g., Kinman, 2001). Our study also showed evidence of long working hours (i.e., $78 \%$ of A\&R staff reported working between 41-61 or more hours in a typical week) and, compared to the norm, A\&R staff reported higher levels of stress for these two subscales. Irrespective of category of employee, however, levels of stress for both of these subscales were lower than the norm. What was also interesting was that, whilst A\&R staff reported the highest levels of stress for worklife balance and overload, both compared to the norm and other categories of employee, they did not report the highest levels of stress outcomes. Indeed, they reported the lowest levels of physical ill-health. Thus, these results again suggest a protective effect of job satisfaction for $A \& R$ staff and that $A \& R$ staff are still 'engaged' in the work they do.
As predictors of stress and job satisfaction, our findings showed a minimal relationship between personal and job characteristics. Indeed, category of employee and type of contract together only explained $2.5 \%$ of the variance in job satisfaction, gender and salary together only explained $5 \%$ of the variance in physical illhealth, and gender only explained $1 \%$ of the variance in psychological ill-health. These small contributions made by personal and job characteristics were also found by Mechteld et al. (2003) and, thus, our results also highlight the importance of considering organisational rather than personal factors as predictors of stress and satisfaction. The strongest predictor of job satisfaction, making a contribution of 39\%, was high levels of job control. This fits with Karasek's (1979) Demand-Control theory of job stress, which states that jobs high in both demand and control are seen as 'active' but not stressful. Interestingly, however, our sample reported lower levels of job control compared to the norm, although they were obviously at high enough levels to contribute significantly to levels of job satisfaction. High job control did not contribute as a predictor for physical health. In this model, high levels of job satisfaction were the strongest predictor, making a contribution of $13 \%$. As an outcome variable in itself, when job satisfaction was excluded from the model, work relationships became the strongest predictor, making a contribution of $11 \%$. Irrespective of whether or not job satisfaction was included in the model, having good working relationships was also the strongest predictor for psychological health, making a contribution of $21 \%$.

Analysis of the results by item showed that, from a 'physical' perspective and compared to the norm, job satisfaction was improved by having a better physical working environment, as well as a lower risk of actual physical violence. As might be predicted due to the nature of their work, having better 'physical' conditions was more of a problem (although still at normative levels) for Academic-support and Facility-support staff compared to $A \& R$ and $A \& C$ staff. From a more 'psychological' perspective, apart from Facility-support staff, job satisfaction was improved by not being closely monitored at work and not having to deal with difficult customers/clients. For A\&R staff, job satisfaction was improved by their work not being dull and repetitive.

In summary, therefore, the aim of this paper was to focus on the more positive aspects of working in academia and to highlight some of the things which HEIs (at least in our sample) appear to be doing right. Our results show that HEI staff, particularly A\&R, are still largely satisfied with their jobs and that, for the moment at least, this seems to be making a protective contribution to their physical health. With significant differences being reported by category of employee, our results also show that what is positive for one occupational group can largely be determined by the types of work they do and they way in which they are allowed to do it. For example, although these are decreasing, compared to other occupational groups, A\&R staff still have higher levels of autonomy and control. Whilst flexible working hours are an option, it is not always one which organisations can practically provide (e.g., flexible working hours might not be suitable for a baker).

In conclusion, our study demonstrates that, whilst employers ultimately need to address the hotspot areas of stress identified by their risk assessments and in-house surveys, they can still benefit from being more proactive in their battle against workplace stress by providing work environments in which employees are motivated and feel satisfied by the jobs they do. As identified by (Wilson, 1996, p. 1), 'an unmet need can frustrate an employee and will continue to influence their behaviour until it is satisfied; managers can therefore effectively work with an employee by identifying the level of need which s/he is trying to satisfy and by attempting to build opportunities in the work environment that will allow them to satisfy their own needs'. Our study has shown that a sample of 14 HEIs across England appear to be doing this and, as such, are providing a fortigenic approach to occupational stress. 


\section{ACKNOWLEDGEMENTS}

This research is funded by the Higher Education Funding Council for England. Special thanks also go to Christine Webb, Cary Cooper, Pam Jacobs and Chris Ricketts for their contribution to the writing of this paper.

\section{REFERENCES}

Altbach, P.G. (1996). The international academic profession. Princeton, NJ: Carnegie Foundation for the Advancement of Teaching.

AUT. (1990). Goodwill under stress: Morale in UK universities. London: Association of University Teachers.

Banks, M.H., Clegg, C.W., Jackson, P.R., Kemp, N.J., Stafford, E.M. \& Wall, T.D. (1980). The use of the General Health Questionnaire as an indicator of mental health in occupational studies. Journal of Occupational Psychology, 53, 187-194.

Boyd, S. \& Wylie, C. (1994). Workload and stress in New Zealand universities. Wellington: New Zealand Council for Educational Research and the Association of University Staff of New Zealand.

Bradley, J. \& Eachus, P. (1995). Occupational atress within a UK higher education institution. International Journal of Stress Management, 2 (3), 145-158.

Cartwright, S. \& Cooper, C. L. (2002). ASSET: An organizational stress screening tool - The management guide. Manchester: RCL.

Cooper, C., Sloan, S.J. \& Williams, S. (1988). Occupational Stress Indicator: Management guide. Windsor: NFER Nelson.

Cranny, C.J., Smith, P.C. \& Stone, E.F. (1992). Job satisfaction: How people feel about their jobs and how it affects their performance. New York: Lexington Books.

Doyle, C. \& Hind, P. (1998). Occupational stress, burnout and job status in female academics. Gender, Work and Organisation, 5, 67-82

Executive, H.A.S. (2000). The Scale of Occupational Stress: The Bristol stress and health at work study.

Fisher, S. (1994). Stress in academic life: The mental assembly line. Buckingham: SHRE and Open University Press.

French, J.R.P., Caplan, R.D. \& Van Harrison, R. (1982). The mechanisms of job stress and strain. Buckingham: Open University Press.

Gillespie, N.A., Walsh, M., Winefield, A.H., Dua, J. \& Stough, C. (2001). Occupational stress in universities: Staff perceptions of the causes, consequences and moderators of stress. Work and Stress, 15 (1), 53-72.

Goldberg, D.P. \& Williams, P. (1988). A user's guide to the GHQ. London: NFER, Nelson.

Howard, J.L. \& Frink, D.D. (1996). The effects of organizational restructure on employee job satisfaction. Group and Organization Management, 21, 278-303.

Iadaffaldano, M.T. \& Muchinsky, P.M. (1985). Job satisfaction and job performance: A meta-analysis. Psychological Bulletin, 87, 251-273.

Johnson, S. \& Cooper, C. (in press). The construct validity of the ASSET Stress Measure. Work and Stress.

Jones, F. \& Bright, J. (2001). Stress: Myth, theory and research. London: Pearson Educational.

Karasek, R. (1979). Job demands, job decision latitude and mental strain: Implications for job redesign. Administrative Science Quarterly, 24, 285-308.

Kinman, G. (2001). Pressure points: A review of stressors and strains in UK academics. Educational Psychology, 21, 474-492.

Kinman, G. \& Jones, F. (2003). 'Running up the down escalator': Stressors and strains in UK academics. Quality in Higher Education, 9 (1), 22-38.
Lacy, F.J. \& Sheehan, B.A. (1997). Job satisfaction among academic staff: An international perspective. Higher Education, 34, 305-322

Makin, P.J., Cooper, C. \& Cox, C.J. (1996). Organizations and the psychological contract: Managing people at work. Leicester: British Psychological Society.

McInnis, C. (1996). Change and diversity in the work patterns of Australian academics. Higher Education Management, 8 (2), 105-117.

McInnis, C. (1999). The work roles of academics in Australian universities. Melbourne: Department of Education, Training and Youth Affairs.

Mechteld, R.M., Visser, E.M.A., Smets, F.J. \& Oort, C.J.M. (2003) Stress, satisfaction and burnout among Dutch medical specialists. Canadian Medical Association Journal, 168, 271 275 .

Millward-Brown. (1996). Powerful people: A survey of Britain's professional workforce. Guardian Publishing Group.

Office for National Statistics (2003). New earnings survey. http://www.statistics.gov.uk/cci/nugget.asp?id=285

Ramirez, A.J., Graham, J., Richards, M.A., Cull, A. \& Gregory, W.M. (1996). Mental health of hospital consultants: The effects of stress and satisfaction at work. Lancet, 347, 724-728.

Rose, M.J. (1999). Forecasting job satisfaction in Britain: What occupational profiling tells us. Bath: University of Bath.

Rothmann, S. (2003). Burnout and engagement: A fortigenic perspective: Research Unit "Decision-making and Management for Economic Development", School of Human Resource Sciences, Potchefstroom University for $\mathrm{CHE}$

Ryan, R.M. \& Deci, E.L. (2000). Self-determination theory and the facilitation of intrinsic motivation, social development, and well-being. American Psychologist, 55, 68-78.

Schaufeli, W.B. \& Bakker, A.R. (2001). Werk en welbevinden: Naar een positieve benadering in de Arbeids- en Gezonheidspsychologie [Work and wellbeing: Towards a positive occupational health psychology]. Gedrag en Organizatie, 14, 229-253.

Seligman, M.E.P. \& Csikszentmihayli, M. (2000). Positive psychology: An introduction. American Psychologist, 55, 5-14.

SPSS Inc. Headquarters, 233 S. Wacker Drive, 11th floor, Chicago, Illinois 60606. http://www.spss.com/uk/ n ukcrreward.htm

Staw, B.M. (1986). Organizational psychology and the pursuit of the happy/productive worker. California Management Review, 28, 40-53.

Strümpfer, D.J.W. (2000). Psychofortology: Review of a paradigm marching on. TBA.

Warr, P.B., Cook, J. \& Wall, T.D. (1979). Scales for the measurement of work attitudes and aspects of psychological well-being. Journal of Occupational Psychology, 52, 129-148.

Watts, W.D., Cox, L., Wright, L.S., Garrison, J., Herkimer, A. \& Howze, H.H. (1991). Correlates of drinking and drug use by higher education faculty and staff: Implications for prevention. Journal of Drug Education, 21, 43-64.

Willie, R. \& Stecklein, J.E. (1982). A three-decade comparison of college faculty characteristics, satisfactions, activities and attitudes. Research in Higher Education, 16, 81-93.

Wilson, P. (1996). Job satisfaction: A review of the literature. Retrieved 08/08/2003, 2003, from http://www.geocities. com/Paris/Cafe/5839/writings/satisfaction.html

Winefield, A., Gillespie, N., Stough, C., Dua, J., Hapuararchchi, J. \& Boyd, C. (in press). Occupational stress in Australian university staff: Results from a national survey. International Journal of Stress Management.

Winter, R. \& Sarros, J. (2002). The academic work environment in Australian universities: A motivating place to work? Higher Education Research \& Development, 21, 241-258. 